\title{
Costs Associated With Compressed Natural Gas Vehicle Fueling Infrastructure
}

Factors to consider in the implementation of fueling stations and equipment

Margaret Smith, New West Technologies (DOE HQ Technical Support)

John Gonzales, National Renewable Energy Laboratory

This document has been peer reviewed by the natural gas industry.

September 2014

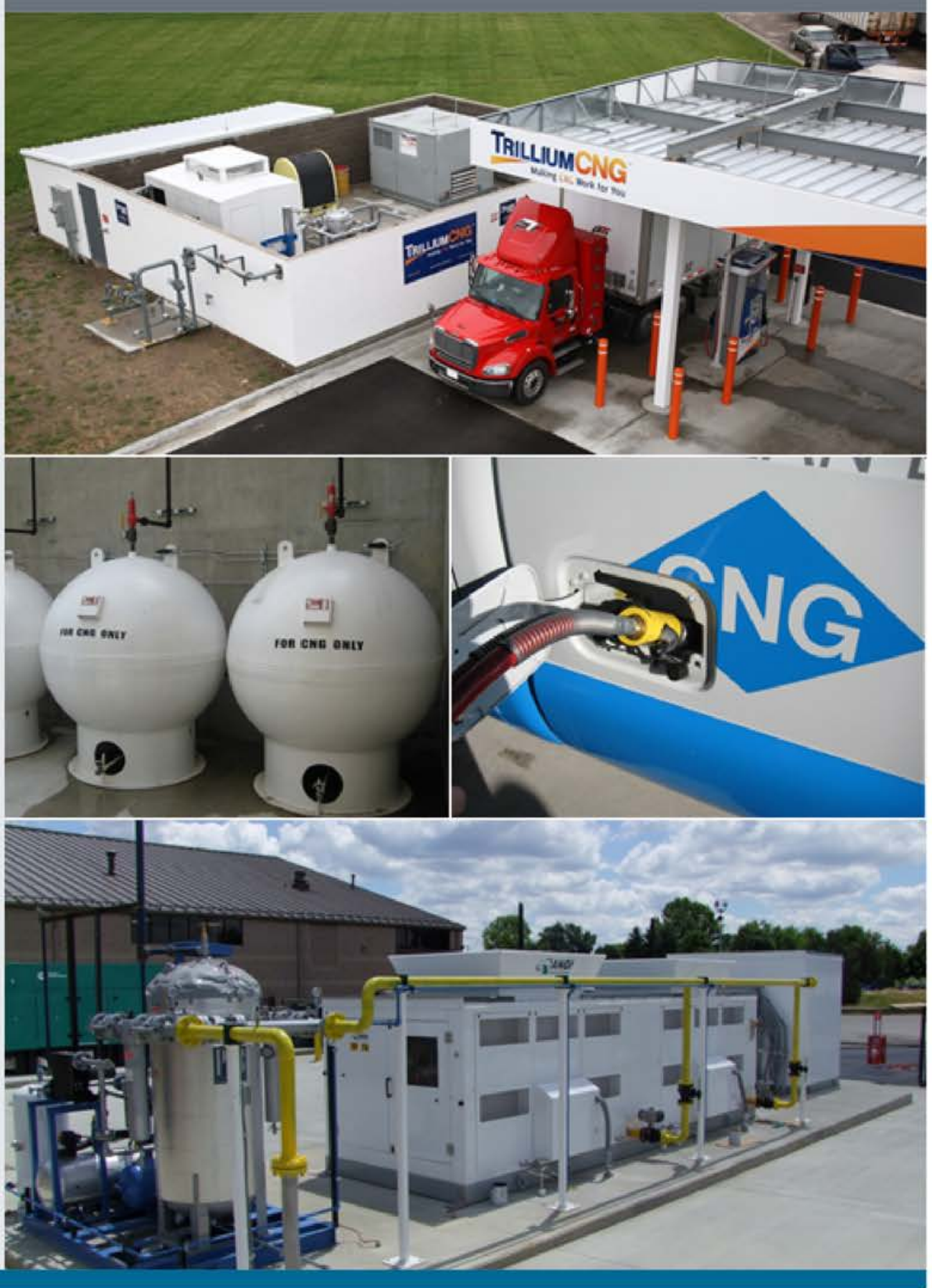




\section{Introduction}

This document is designed to help fleets understand the cost factors associated with fueling infrastructure for compressed natural gas $(\mathrm{CNG})$ vehicles. It provides estimated cost ranges for various sizes and types of CNG fueling stations and an overview of factors that contribute to the total cost of an installed station. The information presented is based on input from professionals in the natural gas industry who design, sell equipment for, and/or own and operate CNG stations.

The total cost of developing a $\mathrm{CNG}$ fueling station depends on a number of factors, including the fuel demand from the fleet and other users, the fleet's applications and duty cycles, site conditions, the complexity of equipment installation, and permitting processes. Consequently, costs can vary widely from one project to another. This document outlines the primary cost factors for fleets' consideration but is not intended to serve as a tool for estimating the cost of an individual project. To obtain an estimate for a specific project, contact a $\mathrm{CNG}$ equipment supplier or engineer who specializes in $\mathrm{CNG}$ station design.

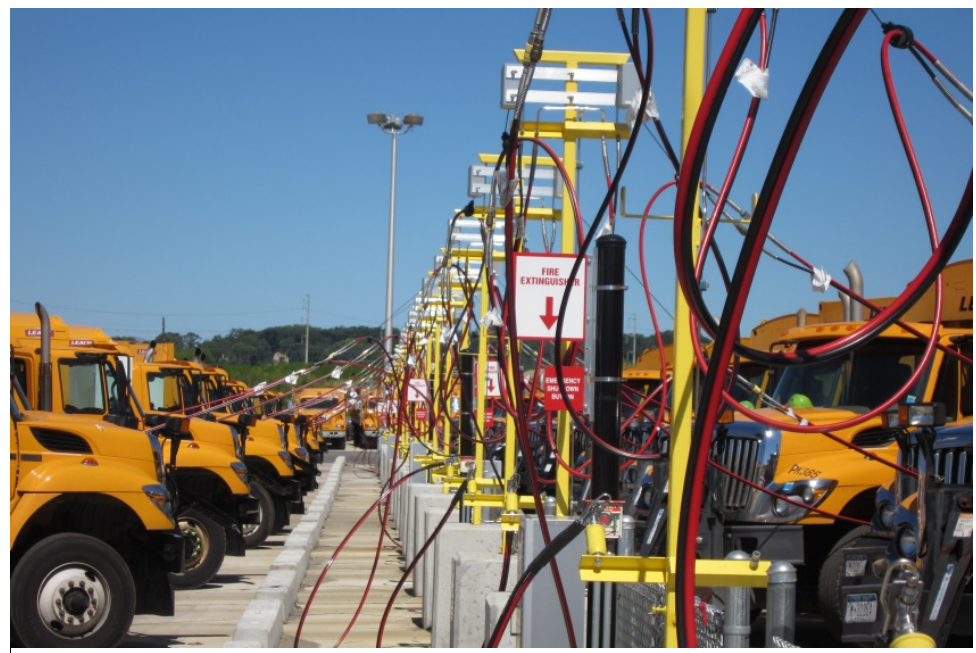

CNG vehicles using time-fill posts in Oyster Bay, New York. Photo from Greater Long Island Clean Cities, NREL 23853

\section{CNG Station Overview}

CNG stations receive fuel via a local utility line at a pressure lower than that used for vehicle fueling. The station compresses the gas to a higher pressure for vehicle fueling. Described below are the three types of CNG stations: fast-fill, time-fill, and combination-fill. The main structural differences are the amount of storage capacity, size of the compressor(s), and dispensing rate.

- Fast-fill: The compressor and storage capacity for fast-fill stations are designed such that drivers experience fill times similar to those for gasoline or diesel fueling stations.

- Time-fill: This equipment fills CNG vehicles over a period of hours and is typically used by fleets with vehicles that fuel at a central location each night. The time it takes to fuel a vehicle depends on the number of vehicles, the amount of fuel required, and the throughput of the compressor. Vehicles are unattended during the fueling process, which may take several minutes to many hours.

- Combination-fill: At combination-fill stations, users have the ability to time-fill or fastfill vehicles on demand. Many fleets use the convenience of time-fill as the primary method of fueling, with fast-fill available as needed.

A CNG station may be accessible only to a private fleet, open to the public, or a combination of the two. Private stations are only available for use by one fleet or several fleets that have 
contracts with the station owner. Fleets use private stations so they can ensure their vehicles have priority for fueling and maximize vehicle operation time. Public stations are openly accessed by fleets and retail consumers; some public stations are only open during specified business hours. They have fuel management systems that allow for payment processing via credit card and fleet fuel card. Public stations are utilized by fleets that prefer not to build, operate or maintain their own infrastructure. Public-private stations are designed for a fleet to fuel its vehicles with fast-fill or time-fill privately, while also providing publicly available (or limited prearranged use) fast-fill dispensers on the

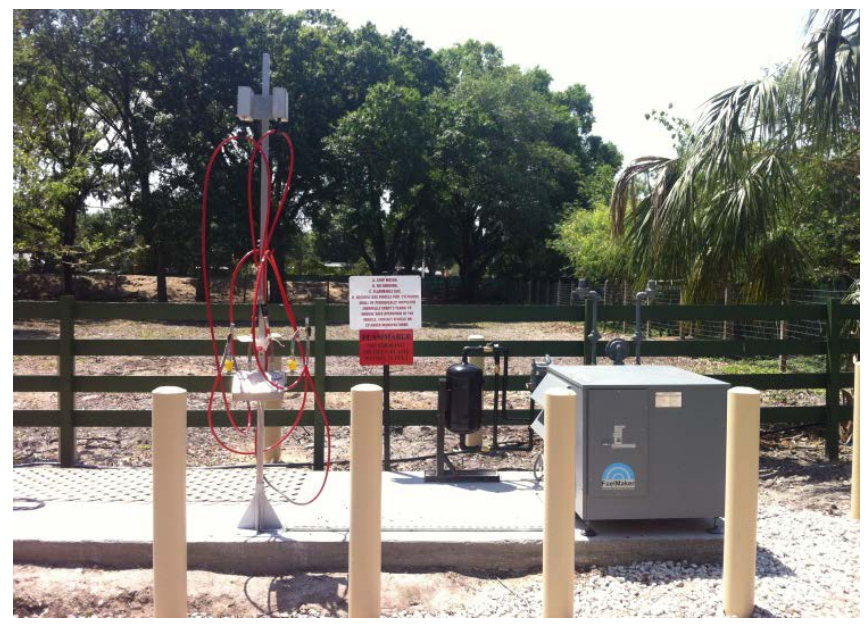

FuelMaker FMQ-8 compressor and dual hose time-fill post in Gulf Breeze, Florida. Photo from Jeremy Talbot, Phoenix Energy Corp, NREL 28228 street side of the fence. A fleet may choose a public-private design to meet fuel supplier throughput requirements, to benefit from economies of scale, or to meet requirements of a grant or incentive.

\section{Factors Affecting CNG Station Costs}

The most significant costs associated with developing a station are those related to land, engineering drawings, station design, equipment, and installation. The actual costs of a given project will vary according to the specific needs and constraints of the station and its users.

\section{User Needs and Access}

\section{Time-Fill and Fast-Fill Designs}

Time-fill stations are designed for vehicles that have a long fueling window. At these stations, vehicles are generally filled directly from the compressor, not from storage tanks. At fast-fill stations, vehicles are filled from high-pressure storage tanks or compressors. Time-fill station development costs are typically lower than those of fast-fill stations, given that time-fill stations generally have smaller compressors and little to no storage. Time-fill stations normally use unmetered fill posts (see photo) instead of metered dispensers. Although fill posts are less expensive than metered dispensers, the station may require more of them because time-fill stations typically have one fill post per one to four vehicles. For larger fleets, a combination-fill station has the advantage of spreading out the fueling load by time-filling overnight and fastfilling throughout the day.

\section{Fleet Size, Fuel Use, and Fueling Window}

Station design is determined by the number of vehicles that fuel at the station, the amount of fuel the vehicles use, and the vehicles' drive and duty cycles and associated fueling windows. Stations that serve large numbers of vehicles with short fueling windows or unpredictable fueling times may require large compressors, greater storage capacity, and/or a large number of dispensers. If vehicle fueling can be staggered on a predictable schedule, a fleet may be able to reduce overall 
costs. Vehicles with high daily fuel use may have longer fill times, which affect fueling schedules. If these vehicles have short fueling windows, they may require a CNG station with significant storage or compression capacity.

\section{Public, Private, or Public-Private Access}

Some design and operational differences among public, private, and public-private stations can affect costs. Public-access stations usually require liability insurance. A public-private station has multiple fueling areas, and there is an additional cost associated with extending the power and gas line to the public dispenser(s). A public-private station may have greater operating costs related to accounting and billing compared to a private station. If a fast-fill station is designed for fueling many vehicles with short fueling windows, it may require larger compressors and more storage capacity than would a site that serves the same number of vehicles with longer fueling windows.

\section{Installation and Site Parameters}

\section{Inlet Gas Pressure}

The available gas pressure (inlet pressure) in the supply gas line can have a significant impact (positive or negative) on station costs. If a site has low gas pressure in the gas line, additional compression and/or higher horsepower may be needed, which will increase capital and operating costs. It may be possible to increase the site's gas pressure at an additional cost, but if not, in very low pressure situations, it may be advantageous to find another fueling site. Gas boosters are available to help increase pressure. Conversely, if a site has high gas pressure in the gas line, costs associated with compressors may be lower than average. Operational costs may also be lower in this scenario, because less power will be needed to achieve a given fueling rate. Natural gas utilities typically operate lowpressure (less than $1 / 2$ pounds per square inch gauge [psig]), medium-pressure (5-60 psig), and high-pressure (greater than 100 psig) systems in the United States. It is desirable for largecapacity stations to be installed on high-pressure

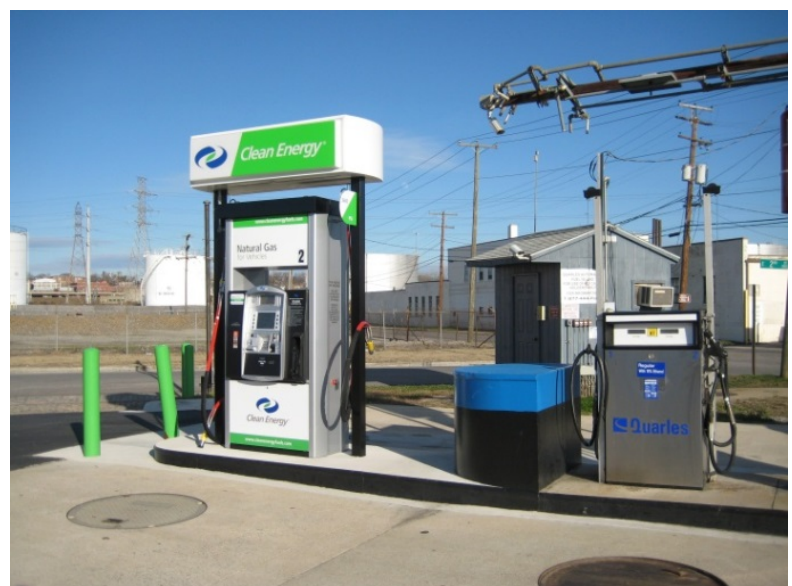

CNG station installed at an existing gas station in Richmond, Virginia. Photo from Margaret Smith, DOE, NREL 28005 gas lines. On a high-pressure line, a regulator may be required to regulate the gas pressure to meet the compressor requirements.

\section{CNG Station Installation}

CNG station installation costs include those associated with laying concrete, trenching, ductwork, plumbing, electrical connection and upgrades, and material shipping. Many factors affect installation costs, including the following:

- Site layout - This must take into account the distances to buildings and property lines. 
- Available power supply-If a site does not have adequate electrical capacity for $\mathrm{CNG}$ fueling equipment, an electrical upgrade may be necessary.

- Space constraints-A site with space constraints may require additional engineering and installation costs.

- Proximity to gas pipeline-If the gas line needs to be brought closer to the station

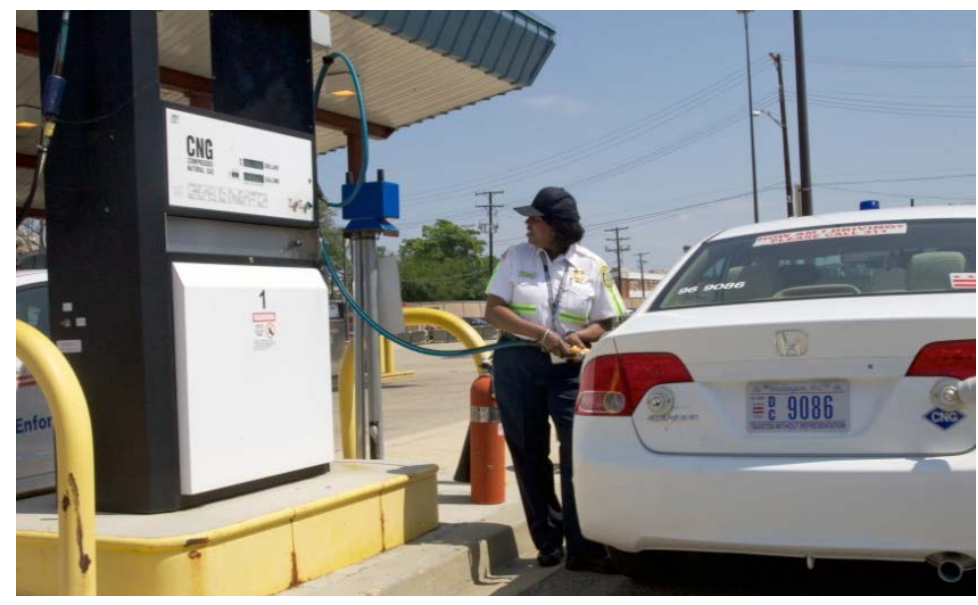

A Washington, D.C., government worker fuels a CNG Honda Civic. Photo from Kaye Evans, PR Newswire, NREL 18250 site, it will result in additional costs. Depending on the circumstances, such as the fleet committing to a minimum throughput volume, the utility may cover a portion of this cost.

The following site considerations also affect station installation costs:

- $\quad$ Signage, lighting, and security fencing

- Availability of other types of fuels to be dispensed from the same location

- Indoor fueling, which adds significant costs because of its specialized construction and high-specification heating and electrical equipment

- Fueling island canopy, which may increase station cost by $\$ 20,000$ to $\$ 80,000$

- Size and weight of vehicles to be served by the station, which affect pavement type and turn-radius requirements

- Soil conditions, which can impact foundation requirements

- Driveways, grading, and other general site upgrades.

\section{Land Costs, Due Diligence, and General Site Work}

The site location and preparation needed for the CNG station will have a significant effect on the overall development cost. Land costs vary based on many factors, such as location and size. Prior to installing CNG fueling equipment, general site work may be needed, such as grading, filling, compacting, paving, and stormwater management. A developer may incur additional costs for due diligence measures, such as a geotechnical survey of the site to ensure the soil conditions can support the weight of the station equipment. Completing environmental site assessments can help a developer determine whether the purchased land has previously been contaminated by hazardous materials. 


\section{Project Management}

Increased costs may result from project management challenges, such as supplier reliability, expediting equipment delivery or installation, or regional labor costs. Research into the experience and qualifications of vendors and engineering service providers should help to avoid any unnecessary costs.

\section{Station Commissioning}

After the CNG station equipment is installed, a commissioning process ensures the station functions properly. During this process, the station components are tested under various conditions, and adjustments are made if needed. Commissioning may be performed by the contractor who built the station or by a third-party expert. When soliciting proposals for building a $\mathrm{CNG}$ station, developers are encouraged to require station commissioning is included in proposals. The contract established with

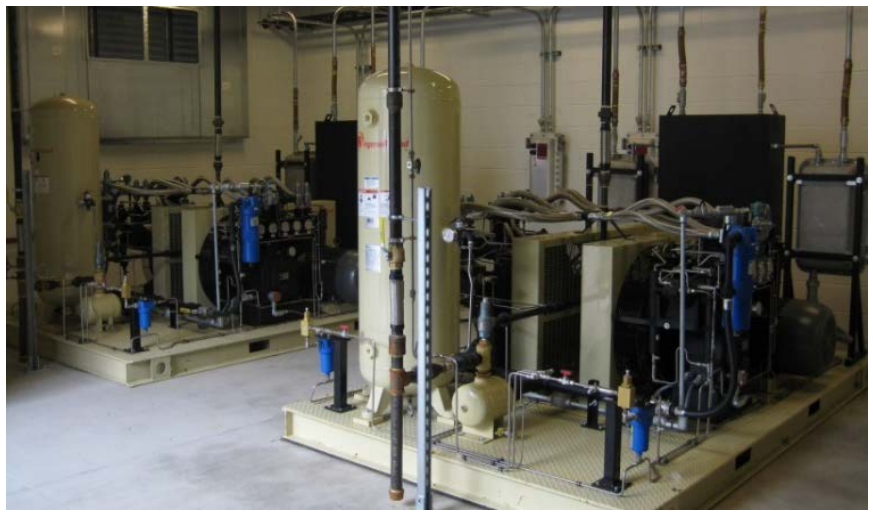

Redundant compressors at Washington Gas in Springfield, Virginia. Photo from Margaret Smith, DOE, NREL 28171 a station provider should specify within the performance clause that the work must pass a commissioning process. It is beneficial for the entity that will perform station maintenance to be present during commissioning.

\section{Station Design}

\section{Engineering Drawings}

It is important to work with an experienced engineer to design a station that best meets the owner's needs. As described throughout this document, there are many design parameters that must be tailored to vehicle requirements, site constraints, budgets, long-term plans, and location. The cost of engineering drawings can range from approximately $\$ 10,000$ to $\$ 40,000$, depending on the size and complexity of the station.

\section{Compressor Redundancy}

It is considered a best practice to design a station with multiple compressors so that the total compressor power is greater than what is necessary for the anticipated fuel throughput. Installing additional compressors, which is referred to as compressor redundancy, allows the station to continue operating in the event that one compressor stops functioning or is undergoing scheduled maintenance. A fleet may choose a design with $100 \%$ redundancy. A lower-cost design option is to have two compressors, each capable of providing $50 \%$ to $70 \%$ of the total required flow. In this scenario, fleets typically select two identical compressors because they will have the same 
maintenance procedures and spare parts. This option allows the main compressor to run until the demand for fuel requires the second compressor to start.

\section{Compressor Enclosures}

Some compressors are protected from inclement weather to prevent premature wear and reliability issues. A shelter can be constructed around the compressor, or the compressor can be enclosed in a box. Canopy shelters provide ample space to perform maintenance on the compressor but may not provide full protection from rain and snow. Enclosures are transportable, require less space than a canopy, provide good weather protection, and reduce compressor noise. However, there is very little room to perform maintenance on enclosed compressors. Basic compressor enclosures add approximately $10 \%$ to the cost of the compressor.

\section{Planning for Growth}

If a station is designed to accommodate an

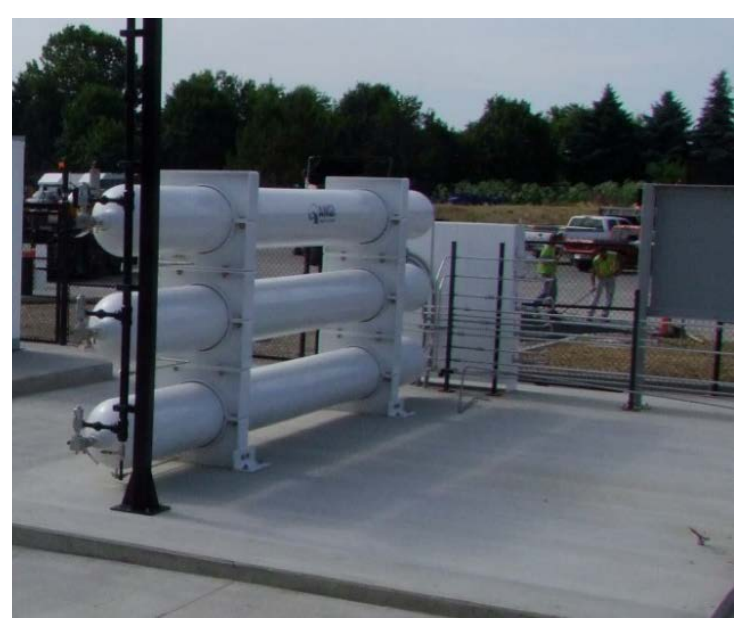

This CNG station was built with three storage vessels and has space on the concrete slab to add more storage vessels in the future. Photo from Marathon Technical Services, NREL 30345 anticipated future increase in throughput, there may be additional initial costs associated with station development. However, such investments may result in less expensive upgrades and expansions in the long run. For example, a single compressor can be installed in the initial phase, with a second compressor added as demand increases. This also builds in redundancy. Similarly, leaving space and planning for utility lines to serve additional dispensers and/or more storage may save time and money in the future. Skid-mounted systems are convenient for growing fleets because they can be easily replaced with larger systems.

\section{Regulatory and Permitting Issues}

Regulatory and permitting requirements can be significant factors in the costs associated with station engineering, equipment, and installation. The cost and lead time required for obtaining necessary permits will vary based on the relevant jurisdiction(s). Engaging the authorities having jurisdiction (AHJs) at the outset of the project will ultimately simplify the permitting process. Fire marshals, zoning boards, and permitting agencies are examples of AHJs. Some AHJs may have extensive requirements pertaining to fire detection and extinguishing systems or seismic design. Americans with Disabilities Act compliance may also affect the cost of the station or other facility design parameters.

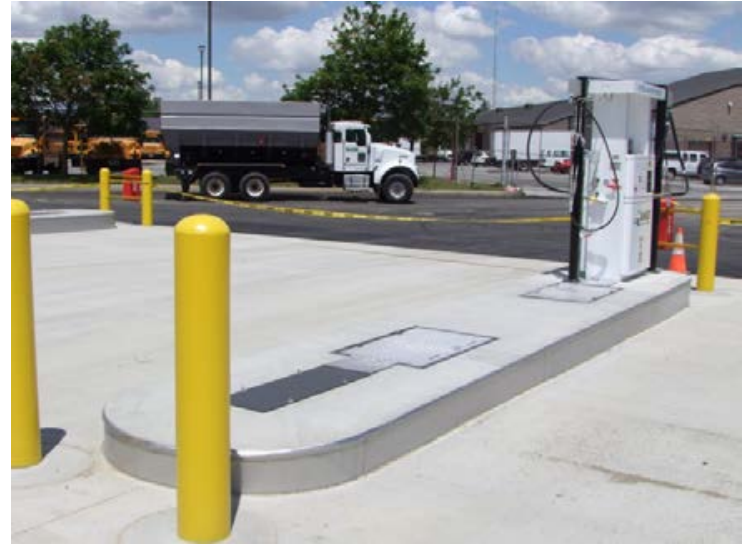

This CNG station was built with one dispenser and has concrete poured to easily install three more dispensers in the future. Photo from Marathon Technical Services, NREL 30344 


\section{Metering System}

Choosing to meter only the total fuel flow at the station, rather than metering the amount used at each fast-fill dispenser, can typically decrease equipment costs by approximately $\$ 15,000$ per hose. However, metering only total fuel flow may not allow for necessary data collection related to taxes, revenues, expenses, or vehicle preventive maintenance.

\section{Backup Power Generator}

Natural gas or diesel generators can be used to produce electricity to run the compressor and auxiliary equipment in the event of a power outage. Generator costs can range from $\$ 50,000$ to $\$ 250,000$, depending on the size of the compressor it supports.

\section{Other Factors to Consider}

\section{Operations and Maintenance}

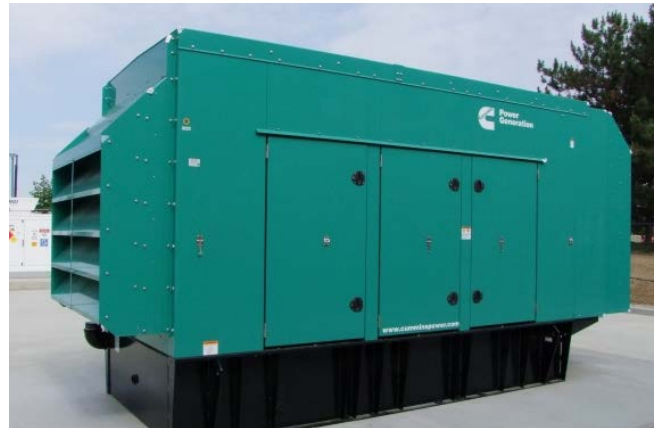

A power generator that can supply electricity to the CNG station in the event of a power outage. Photo from Marathon Technical Services, NREL 30346

Operational costs such as electricity, insurance, and accounting software should be taken into consideration and accounted for in the fuel price. Electricity charges include consumption and demand charges, which vary across the country. The accounting system processes fuel purchases and ensures that relevant federal, state, and municipal motor vehicle sales taxes are applied. It is important to note that a maintenance contract is

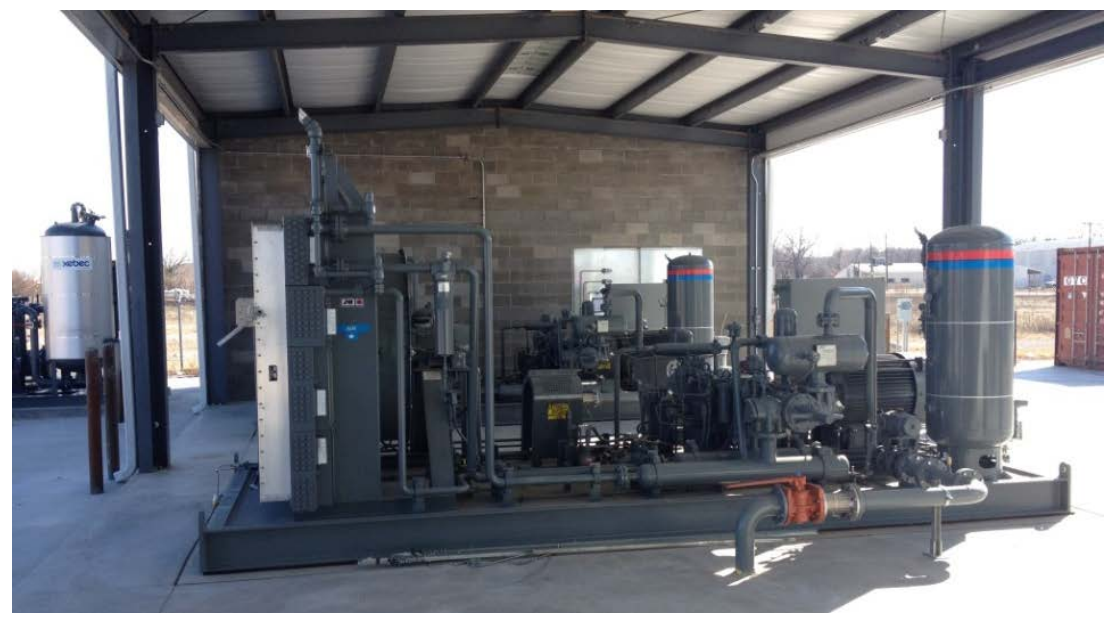

Two compressors protected from inclement weather by a canopy with easy access for maintenance. Photo from Tulsa Gas Technologies, NREL 30246 critical for the long-term performance of a station. Minor preventive maintenance is scheduled on a regular basis, along with periodic major maintenance activities.

\section{Geographic Location and Weather}

Geographic location and weather impact the costs of equipment, installation, and permitting. In extremely cold climates, more elaborate equipment may be needed, including additional heaters. Regions prone to earthquakes may have seismic design requirements. Inclement weather during construction can add to installation costs. For example, a project may incur expenses related to keeping water out of trenches. Equipment and construction costs vary from one region to the next. 


\section{Mobile Onsite Fueling}

Though not yet a common practice, some fleets are exploring mobile onsite CNG fueling options, also known as "wet hosing." In this scenario, all vehicles return to the yard in the evening, and a $\mathrm{CNG}$ supplier fuels the vehicles overnight. A fleet may choose this option instead of building onsite infrastructure. Mobile onsite fueling can also be used as a temporary arrangement when $\mathrm{CNG}$

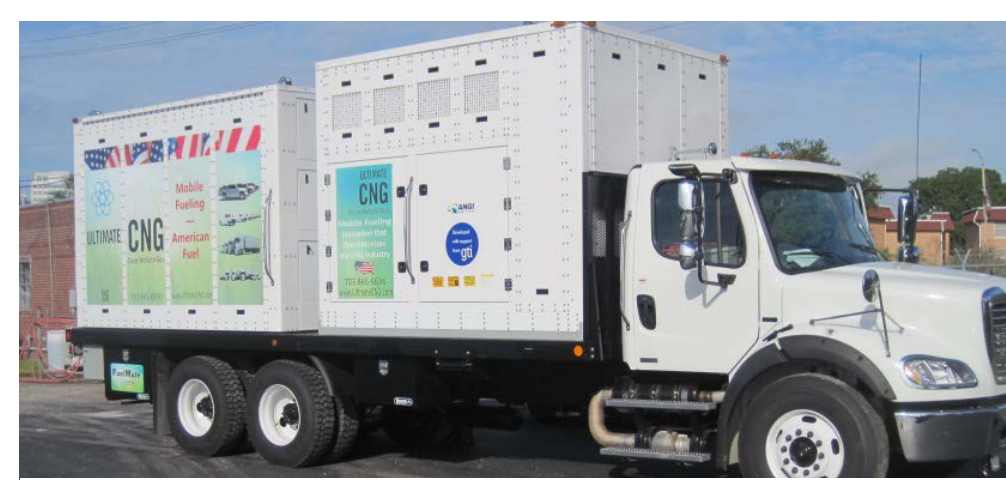

FuelMule from Ultimate CNG is a mobile, self-contained CNG station providing onsite fast-fill fuel delivery. Photo from Ultimate CNG, LLC

vehicles arrive before infrastructure is operational or when infrastructure is out of service. This option may not be available in all geographic areas. A fleet should consult local code authorities to identify any restrictions to mobile fueling.

\section{Renewable Natural Gas}

Renewable natural gas (RNG), produced at locations such as landfills or dairy farms, can supply gas to onsite fueling infrastructure for vehicles such as refuse haulers and dairy trucks. There are equipment costs associated with refining RNG into pipeline-quality gas. Once the RNG has been refined, equipment and installation costs for a fueling station using RNG are similar to

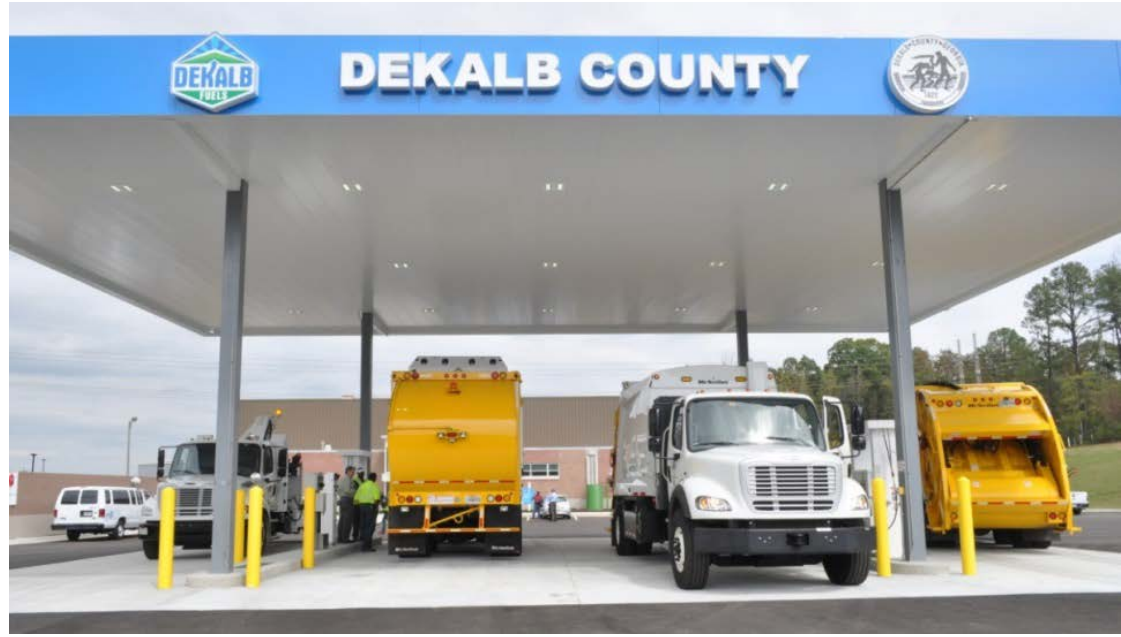

This CNG fueling station in DeKalb County, Georgia, dispenses RNG made from landfill gas. Photo from Robert Gordon, DeKalb County, NREL 26760 those for a fueling station that is connected to a utility pipeline. For more information about RNG, visit afdc.energy.gov/fuels/emerging biogas.html.

\section{Transit Bus Fleets}

If you have a transit bus fleet, transit stations require special considerations because they must fuel large numbers of vehicles with high volumes of fuel in short-fill windows (e.g., 20 to 300 buses requiring 30 to 50 diesel gallon equivalents per day, all within a four- to eight-hour fueling window). Instead of the traditional fast-fill design, these stations are typically designed to fuel vehicles directly from the compressors and have lower station storage capacity. They have multiple large compressors, and buses may be fueled indoors while being cleaned. Consequently, these stations require significantly more engineering and are typically more costly than stations serving other types of fleets. 


\section{Estimated CNG Station Costs}

The tables below provide estimated cost ranges for CNG stations of various daily fuel demands. These estimates include the costs of engineering, equipment, and installation at a site with the specified assumptions. The estimates do not include costs associated with unusually complicated installations, difficult permitting issues, compressor redundancy, or similar factors that could increase the total project cost.

Unless otherwise noted, the estimates for fast-fill stations assume a vehicle fueling window in which $70 \%$ of the fuel is dispensed during two hours in the morning and two hours in the afternoon. For time-fill stations, the compressor is assumed to run for 10 hours per day. Fast-fill cost estimates for the small, medium, and large stations include a priority panel and credit card reader. All scenarios include a gas dryer.

It is important to note that the cost of a CNG station may vary substantially from the estimates listed here. Contact a CNG equipment supplier or engineer who specializes in CNG station design to determine the appropriate design and cost for a specific application.

\section{Basic Time-Fill (5-10 gge*/day)}

\begin{tabular}{|c|c|l|l|}
\hline Type & Cost Range & \multicolumn{1}{|c|}{ Example Applications } & \multicolumn{1}{|c|}{ Assumptions } \\
\hline Time-Fill & $\begin{array}{c}\$ 5,500- \\
\$ 6,500\end{array}$ & $\begin{array}{l}\text { One personal vehicle fueling up to 5 } \\
\text { gge/night inside a residential garage }\end{array}$ & $\begin{array}{l}\bullet \text { One 1-scfm compressor (0.48 gge/hr) } \\
\bullet 1 / 4-2 \text { psi inlet gas pressure }\end{array}$ \\
\hline Time-Fill & $\begin{array}{l}\$ 9,000- \\
\$ 10,000\end{array}$ & $\begin{array}{l}\text { Private fleet station serving two } \\
\text { sedans/pickups fueling } 5 \text { gge/night } \\
\text { outdoors** }\end{array}$ & $\begin{array}{l}\bullet \text { One 2-scfm (1 gge/hr) compressor } \\
\bullet \text { One dual-hose post }\end{array}$ \\
\hline
\end{tabular}

*1 gge (gasoline gallon equivalent) $=126 \mathrm{scf}$ (standard cubic feet)

**A time-fill station can accommodate more vehicles than hoses if the vehicles do not fuel every day.

\section{Starter Station (20-40 gge*/day)}

\begin{tabular}{|c|c|c|c|}
\hline Type & Cost Range & Example Applications & Assumptions \\
\hline Fast-Fill & $\begin{array}{l}\$ 45,000- \\
\$ 75,000\end{array}$ & $\begin{array}{l}\text { Private fleet station serving up to four } \\
\text { sedans/pickups fueling } 10 \text { gge/day }\end{array}$ & $\begin{array}{l}\text { - One 8-scfm (4 gge/hr) compressor } \\
\text { - 2-5 psi inlet gas pressure } \\
\text { - 3,780 scf storage ( } 30 \text { gge) } \\
\text { - One single-hose dispenser }\end{array}$ \\
\hline Time-Fill & $\begin{array}{l}\$ 35,000- \\
\$ 50,000\end{array}$ & $\begin{array}{l}\text { Private fleet station serving } \\
\text { - Two utility service trucks fueling } 20 \\
\text { gge/night or } \\
\text { - Four delivery vehicles fueling } 10 \\
\text { gge/night** }\end{array}$ & $\begin{array}{l}\text { - One 8-scfm (4 gge/hr) compressor } \\
\text { - 2-5 psi inlet gas pressure } \\
\text { - Two dual-hose posts }\end{array}$ \\
\hline
\end{tabular}




\section{Small Station (100-200 gge*/day)}

\begin{tabular}{|c|c|c|c|}
\hline Type & Cost Range & Example Applications & Assumptions \\
\hline Fast-Fill & $\begin{array}{c}\$ 400,000- \\
\$ 600,000\end{array}$ & $\begin{array}{l}\text { Private fleet station serving: } \\
\text { - } 15-25 \text { pickups/delivery vans fueling } 7 \\
\text { gge/day or } \\
\text { - 9-16 taxis/work trucks fueling } 12 \\
\text { gge/day }\end{array}$ & $\begin{array}{l}\text { - One } 40-75 \mathrm{scfm} \text { (19-24 gge/hr) } \\
\text { compressor } \\
\text { - 5-15 psi inlet gas pressure } \\
\text { - } 16,250 \text { scf storage (129 gge) } \\
\text { - One single-hose metered dispenser } \\
\text { - Included installation costs are estimated at } \\
65 \% \text { of equipment costs }\end{array}$ \\
\hline & $\begin{array}{c}\$ 250,000- \\
\$ 500,000\end{array}$ & $\begin{array}{l}\text { Private fleet station serving: } \\
\text { - } 10-20 \text { school buses fueling } 10 \\
\text { gge/night, } \\
\text { - } 5-10 \text { refuse vehicles fueling } 20 \\
\text { gge/night, or } \\
\text { - } 15-20 \text { sedans/pickups fueling } 7 \\
\text { gge/night** }\end{array}$ & $\begin{array}{l}\text { - One } 20-50 \mathrm{scfm}(10-24 \mathrm{gge} / \mathrm{hr}) \\
\text { compressor } \\
\text { - 5-10 psi inlet gas pressure } \\
\text { - } 10 \text { dual-hose posts } \\
\text { - One time-fill panel; } 10 \text {-hour fueling } \\
\text { window } \\
\text { - Included installation costs are estimated at } \\
65 \% \text { of equipment costs }\end{array}$ \\
\hline
\end{tabular}

*1 gge (gasoline gallon equivalent) $=126 \mathrm{scf}$ (standard cubic feet)

**A time-fill station can accommodate more vehicles than hoses if the vehicles do not fuel every day.

\section{Medium Station (500-800 gge*/day)}

\begin{tabular}{|c|c|c|c|}
\hline Type & Cost Range & Example Applications & Assumptions \\
\hline Fast-Fill & $\begin{array}{c}\$ 700,000- \\
\$ 900,000\end{array}$ & $\begin{array}{l}\text { Public retail station serving } 50-80 \\
\text { light/medium-duty vehicles fueling } 10 \\
\text { gge/day or } \\
\text { Private fleet station serving } 45-65 \\
\text { taxis fueling } 12 \text { gge/day }\end{array}$ & $\begin{array}{l}\text { - One } 180-300 \text { scfm ( } 86-143 \text { gge/hr) } \\
\text { compressor } \\
\text { - } 30 \text { psi inlet gas pressure } \\
\text { - } 34,000 \text { scf storage ( } 270 \text { gge) } \\
\text { - One dual-hose metered dispenser } \\
\text { - Included installation costs are estimated at } \\
65 \% \text { of equipment costs }\end{array}$ \\
\hline $\lim _{\infty}^{\operatorname{Tim} e}$ & $\begin{array}{c}\$ 550,000- \\
\$ 850,000\end{array}$ & $\begin{array}{l}\text { Private fleet station serving: } \\
\text { - 50-80 school buses fueling } 10 \\
\text { gge/night, } \\
\text { - } 25-40 \text { refuse trucks fueling } 20 \\
\text { gge/night, or } \\
\text { - } 75-80 \text { sedans/pick-ups fueling } 7 \\
\text { gge/night** }\end{array}$ & $\begin{array}{l}\text { - One } 100-175 \mathrm{scfm}(48-83 \mathrm{gge} / \mathrm{hr}) \\
\text { compressor } \\
\text { - } 30 \text { psi inlet gas pressure } \\
\text { - } 10-40 \text { dual-hose posts } \\
\text { - One time-fill panel; } 10 \text {-hour fueling } \\
\text { window } \\
\text { - Included installation costs are estimated at } \\
65 \% \text { of equipment costs }\end{array}$ \\
\hline
\end{tabular}

*1 gge (gasoline gallon equivalent) $=126 \mathrm{scf}$ (standard cubic feet)

**A time-fill station can accommodate more vehicles than hoses if the vehicles do not fuel every day. 


\section{Large Station (1,500-2,000 gge*/day)}

\begin{tabular}{|c|c|c|c|}
\hline Type & Cost Range & Example Applications & Assumptions \\
\hline Fast-Fill & $\begin{array}{l}\text { \$1.2-\$1.8 } \\
\text { million }\end{array}$ & $\begin{array}{l}\text { - Large retail station serving light- to } \\
\text { heavy-duty vehicles such as delivery } \\
\text { vans, work trucks, refuse trucks, class } \\
8 \text { tractors, and local fleets, or } \\
\text { - Airport station serving light- and } \\
\text { medium-duty vehicles such as taxis, } \\
\text { shuttle buses, and local fleets** }\end{array}$ & $\begin{array}{l}\text { - Two } 300-400 \mathrm{scfm}(143-190 \mathrm{gge} / \mathrm{hr}) \\
\text { compressors } \\
\text { - } 30 \text { psi inlet gas pressure } \\
\text { - } 55,000 \text { scf storage ( } 437 \text { gge) } \\
\text { - Two dual-hose metered dispensers } \\
\text { - Included installation costs are estimated at } \\
50 \% \text { of equipment costs }\end{array}$ \\
\hline
\end{tabular}

*1 gge (gasoline gallon equivalent) $=126 \mathrm{scf}$ (standard cubic feet)

${ }^{* *}$ A time-fill station can accommodate more vehicles than hoses if the vehicles do not fuel every day.

\section{Equipment Costs}

Actual equipment costs vary based on equipment size, specifications, and manufacturer.

\begin{tabular}{|c|c|c|}
\hline Equipment & Cost Range & Description \\
\hline $\begin{array}{l}\text { Compressor } \\
\\
\begin{array}{l}\text {-8 scfm } \\
(1-4 \mathrm{gge} / \mathrm{hr}) \\
20-40 \mathrm{scfm} \\
(10-19 \mathrm{gge} / \mathrm{hr}) \\
50-75 \mathrm{scfm} \\
(24-36 \mathrm{gge} / \mathrm{hr}) \\
100-150 \mathrm{scfm}(48- \\
71 \mathrm{gge} / \mathrm{hr}) \\
250-650 \mathrm{scfm} \\
(119-310 \mathrm{gge} / \mathrm{hr})\end{array}\end{array}$ & $\begin{array}{l}\$ 4,000-\$ 550,000 \\
\$ 4,000-\$ 22,000 \\
\$ 50,000-\$ 90,000 \\
\$ 80,000-\$ 150,000 \\
\$ 100,000-\$ 250,000 \\
\$ 200,000-\$ 550,000\end{array}$ & $\begin{array}{l}\text { The compressor takes inlet gas at low pressure and compresses it to } \\
\text { the pressure necessary for filling a vehicle to } 3,600 \text { psi. The } \\
\text { compressor's horsepower (HP) rating and the inlet pressure (psi) } \\
\text { determine the flow rate, which is measured in standard cubic feet per } \\
\text { minute (scfm) or gasoline gallon equivalent per hour (gge/hr). } \\
\text { Compressors that offer similar flow rates vary in price based on their } \\
\text { horsepower rating and manufacturer. }\end{array}$ \\
\hline Dispenser & $\$ 25,000-\$ 60,000$ & $\begin{array}{l}\text { At fast-fill stations, drivers use a dispenser to quickly transfer CNG to } \\
\text { the vehicle tank. Dispensers vary in cost depending on the number of } \\
\text { hoses, fuel management system, and other features. }\end{array}$ \\
\hline $\begin{array}{l}\text { Dual-hose } \\
\text { time-fill post }\end{array}$ & $\$ 4,000-\$ 7,000$ & $\begin{array}{l}\text { At time-fill stations, vehicles are connected to a simple fill post, } \\
\text { typically overnight. The tanks are filled as fuel is available, which } \\
\text { depends on the compressor flow rate and the number of vehicles. } \\
\text { Two vehicles can connect to a dual-hose time-fill post. }\end{array}$ \\
\hline Storage tank & $\$ 70,000-\$ 130,000$ & $\begin{array}{l}\text { Once natural gas is compressed, it can be stored in tanks for later use. } \\
\text { The storage capacity and compressor size are balanced to ensure that } \\
\text { fuel is available within the necessary timeframe and the number of } \\
\text { times the compressor turns off and on is minimized. }\end{array}$ \\
\hline $\begin{array}{l}\text { Card reader/fuel } \\
\text { management } \\
\text { system }\end{array}$ & $\$ 10,000-\$ 30,000$ & $\begin{array}{l}\text { Card readers allow the driver to access fuel using a fleet card or credit } \\
\text { card. A fuel management system is software that enables tracking of } \\
\text { driver and vehicle fueling habits. }\end{array}$ \\
\hline Gas dryer & $\$ 10,000-\$ 300,000$ & $\begin{array}{l}\text { A gas dryer removes moisture from the gas prior to compression, } \\
\text { which is a good practice for all CNG stations. }\end{array}$ \\
\hline
\end{tabular}




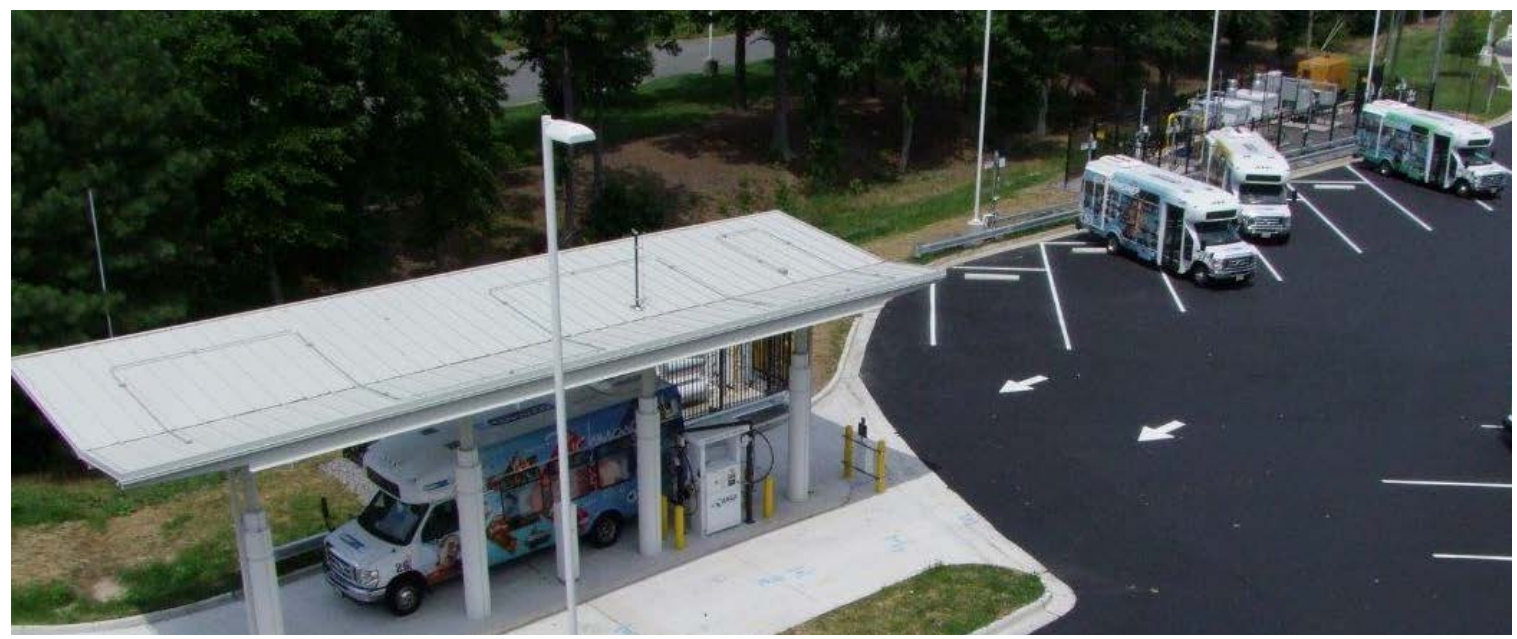

This combination-fill station fuels 14 shuttle buses at the Richmond, Virginia, airport with 14 time-fill posts and two fast-fill hoses. The fast-fill station is in the bottom left, and some of the time-fill posts are in the upper right. Photo from Marathon Technical Services, NREL 30243

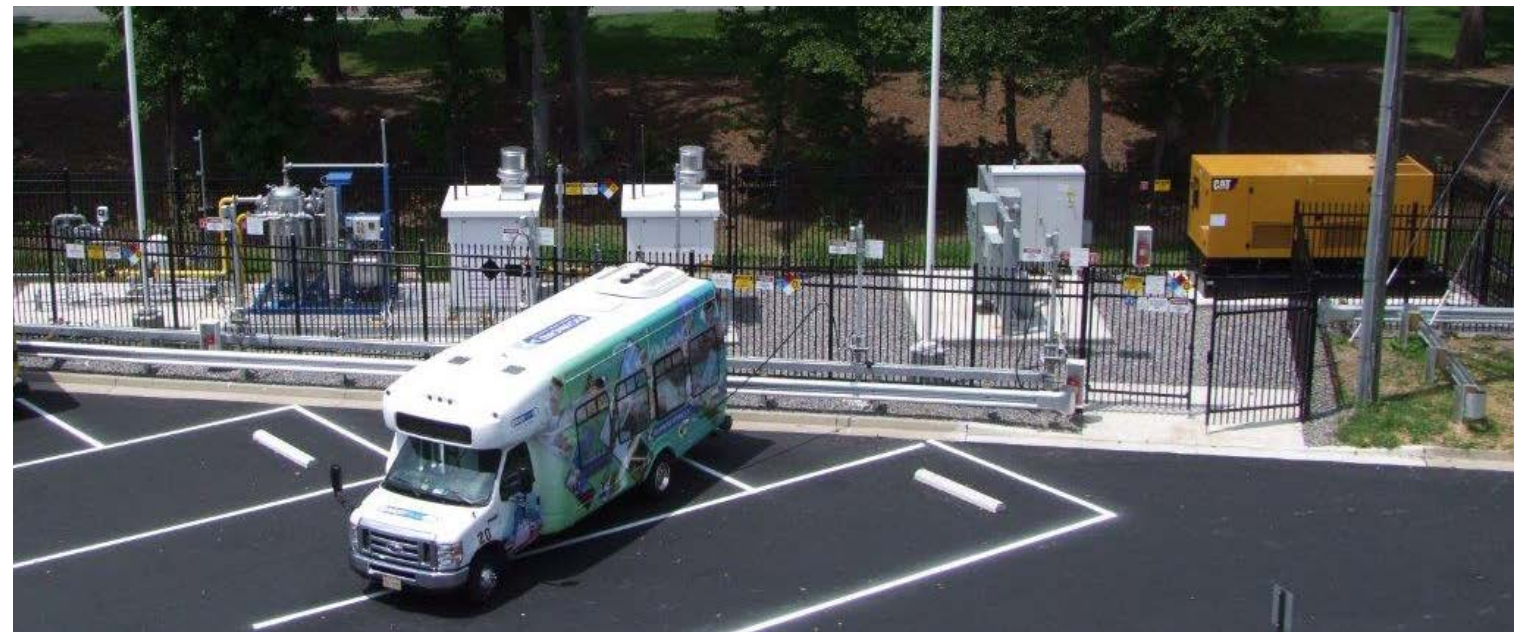

A shuttle bus fuels at a time-fill post at the Richmond Airport combination-fill CNG station. From left to right, the equipment behind the fence is a silver gas dryer, two compressors enclosed in white boxes, electrical system, and a generator at far right. Photo from Marathon Technical Services, NREL 30245

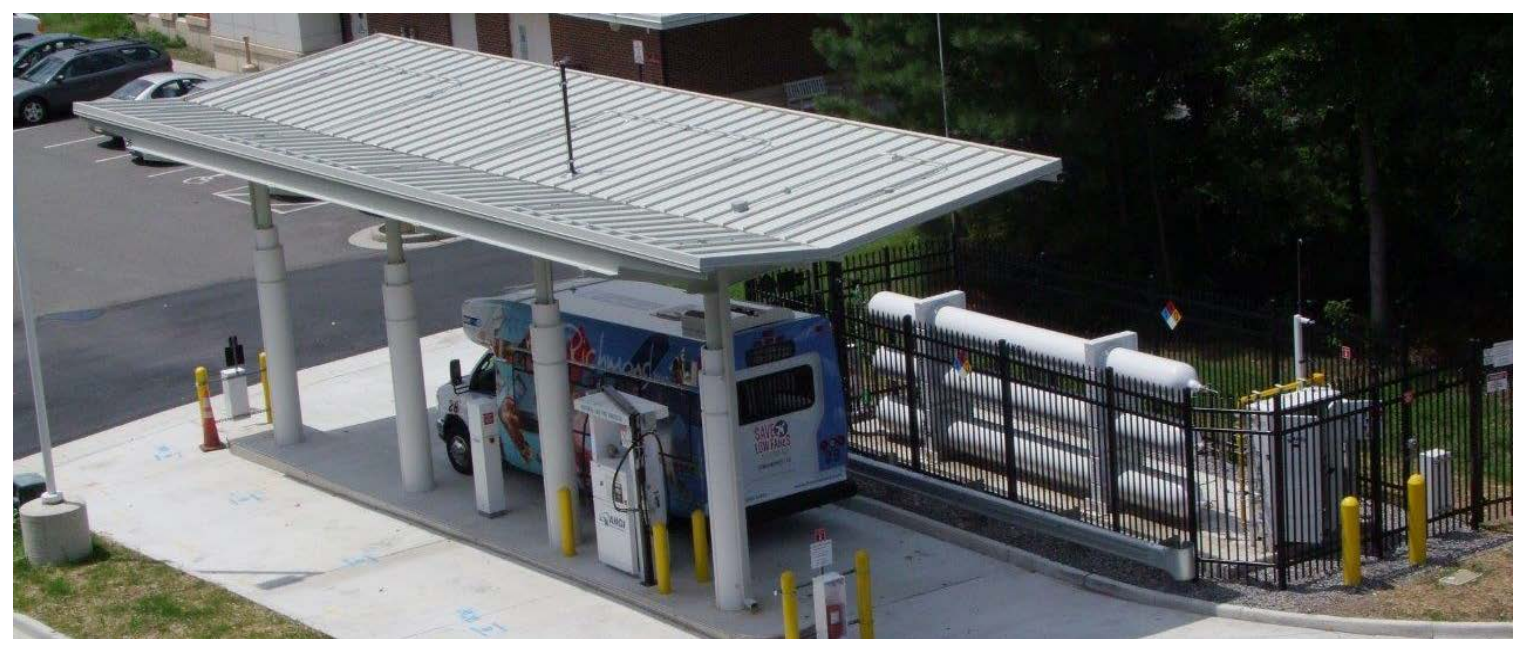

A shuttle bus fuels under a canopy at a fast-fill dispenser at the Richmond Airport combination-fill CNG station. CNG storage vessels are located behind the fence. Photo from Marathon Technical Services, NREL 30244 


\section{Additional Resources}

For more information about CNG stations, visit the Alternative Fuels Data Center (AFDC) at afdc.energy.gov/fuels/natural_gas _cng stations.html. To learn more about the topics introduced in this document, contact your local Clean Cities coalition. Coalition contact information can be found at cleancities.energy.gov.

The Vehicle and Infrastructure Cash-Flow Evaluation (VICE) Model is available on the AFDC at afdc.energy.gov/fuels/natural gas infrastructure.html. Using simple spreadsheet inputs, this model helps fleets estimate the financial and emissions benefits they can expect to achieve by transitioning to CNG. To use the VICE model, users input fleet-specific data, including number of vehicles, vehicle types, fuel use, and planned vehicle-acquisition schedules. The tool then provides numerical and graphical presentations of return on investment, payback period, and annual greenhouse gas savings.

Questions or comments about the information in this document can be sent to cleancities@nrel.gov.

Front Cover Picture Credits:

Trillium CNG, NREL 30247

Margaret Smith

Margaret Smith, NREL 28003

Marathon Technical Services, NREL 30342 
